論

\title{
前照灯照明光源の分光分布が視対象の明るさに与える影響
}

\author{
専門会員 小林 正自((株)小系製作所), 非会員 大川正夫((株)小糸製作所), 専門会員 岡嶋 克典(横浜国立大学 大学院)
}

\section{Study on Effect of Headlight Source Spectrum on Apparent Brightness of Visual Targets}

Fellow Member Shoji Kobayashi (Koito Manufacturing Co, LTD.), Non Member Masao Okawa (Koito Manufacturing Co., LTD. and Fellow Member Katsunori Okajima (Yokohama National University, Graduate School)

\begin{abstract}
In this study, comparative experiments were conducted on the apparent brightness of visual targets illuminated by three types of headlight sources (halogen, HID, and LED), and the results were analyzed in terms of characteristics of visual perception. Those visual targets (with visual size of about 1 degree) were used on an actual road surface and a grey cotton cloth. To compare the apparent brightness under different light sources, we used the matching stimuli presented on the CRT display as a reference. The subjects adjusted the gradation of the matching stimuli until they perceived the brightness of the matching stimuli and that of the sample as equal. Under different light sources, luminance was set to $13 \mathrm{~cd} / \mathrm{m}^{2}$ for the road surface sample and $9.6 \mathrm{~cd} / \mathrm{m}^{2}$ for the grey cotton cloth. A total of 40 subjects aged between 25 and 65 , including three women, participated in the experiment. Their average age was 48 , and four of them wore glasses.

The results indicate that the apparent brightness of road surface differed among the light sources even at the same level of luminance. This demonstrates that the LED light source had higher brightness efficiency than the HID and halogen light sources (meaning that the same brightness can be obtained from the LED light source moreover at a lower level of luminance). Furthermore, such perception changed with observer age, the results for the grey cotton cloth were similar mostly. Instead of the spectral luminous efficiency, $V(\lambda)$, used for the present photometric system, a new spectral sensitivity, $V k(\lambda)$, which takes account of the spectral sensitivity of the short-wave sensitive cones associated with photopic vision, was used for the analysis, and it could accurately explain the experimental results. This suggests that the apparent brightness of white light can be quantitatively compared and evaluated based on the practical effect of luminance of brightness calculated using the spectral sensitivity that takes into consideration the contribution of the short-wave sensitive cones.
\end{abstract}

KEYWORDS : headlight, spectrum distribution, apparent brightness, road surface, achromatic target

\section{1.はじめに}

前照灯の照明光源が白熱電球からハロゲン電球，放電灯(キセ) ンバルブ), LED と高効率光源に進展する各段階で, 我々自動車照明 技術者は路面の見かけの明るさ向上，グレアの増加を実感してき た。そして，その進展過程の中で我々は照明心理面から「同一測光 量であるのに光源の分光分布の相違によりなぜ心理的なグレア量 や見かけの明るさが異なるか？」いう疑問を有してきた。なお， 以下，八ロダン電球を八ロゲン，放電灯(キセノンバルブ)をHID と 略す。

上記のうちの光源の分光分布が見かけの明るさ（以下，単に明る さと記す）に与える影響に関する研究は現在までのところ, 自動車 照明分野では見あたらない。一方, グレアに関する研究は, HID 登 場以降，高齢化の進展も相まって前照灯の眩しさが問題視され，今 日の LED 前照灯まで盛んに研究されてきている.

Sivak らの研究 ${ }^{11}$ や Bullough らの研究 ${ }^{21}$ では, 光源の分光分布が 不快グレアに与える影響を研究し，青色の影響が大であることを示 した。 また橋本らの研究 ${ }^{3)}$ では, 加齢に伴い不快グレアの増大を示 し, 塚田らの研究 4で注色温度の高いものほど不快グレアが增大寸 ることを報告している。しかしながら，これまでの所，測光システ 厶や色覚理論面からの検証が十分になされているとは言い難い.

照明光源の分光分布がグレアや明るさに及ぼす影響を視機能面
から検証できれば，それらの評価モデルの構築に寄与できる。ま た，それらから得られた知見に基づいて夜間照明の改良を実現で きれば，夜間走行の安全性並びに快適性向上に寄与できる，そこ で第1ステップとして前照灯照明光源の分光分布が視対象物の明 るさに与える影響の研究に着手した。

測定視対象はアスフアルト路面とグレ一綿生地の 2 種類を選定 した，前照灯の照明灹源は分光分布の異なるハロダン，HID， LED の 3 種類を選定した. 被験者は 20 代後半から 60 代前半の 40 名 を選定し，加齢の影響も調査することとした。

明るさの測定は, マッチング刺激 (CRT 画面に呈示) と視刘象を 同時呈示し，被驗者がそ机らの明るさが等価と評洒した時のマッ チング刺激の輝度, 即ち等価輝度 (Equivalent luminance; 以下, Leq と略す)を測定する.この Leqを介して加齢の影響及び光源の 分光分布の影響孛解析する.

解析は先ず加齢の影響を解析し，次に主目的である光源の分光 分布の差異がそれに与える影響解析することとした．加齢の影 響の解析は，標準比視感度曲線 $V(\lambda)$ の代替とLて J IS 年代別標 準比視感度曲線 ${ }^{5}$ 使用して検証し, 光源の分光分布の影響につ いては新たな分光感度曲線 $V_{k}(\lambda)$ を立案し検証することとした。

本稿では，2 章でアスファルト路面の実験について記述し，3 章でグレ一綿生地の実験について記述する。 


\section{2.アスファルト路面に対する実験（実験Ｉ）}

\section{1 装置}

前照灯の照明光源による明るさの差を定量的に比較するために

図 1 に示す実験装置を製作した。

装置は，前照灯 (光源) 及び，路面サンプル，路面サンブルの傾き を調整するための回転台，明るさ比較のためのマッチング刺激を呈 示するCRT ディスプレイ，そして外光走遮光し順応輝度が調整可能 な観測室からなる．な抏，光源の変更は前照灯を交換することによ り行なう。これ机暗室 $(\mathrm{L} 10 \mathrm{~m} \times W 5 \mathrm{~m} \times \mathrm{H} 5 \mathrm{~m})$ 内に設置した。

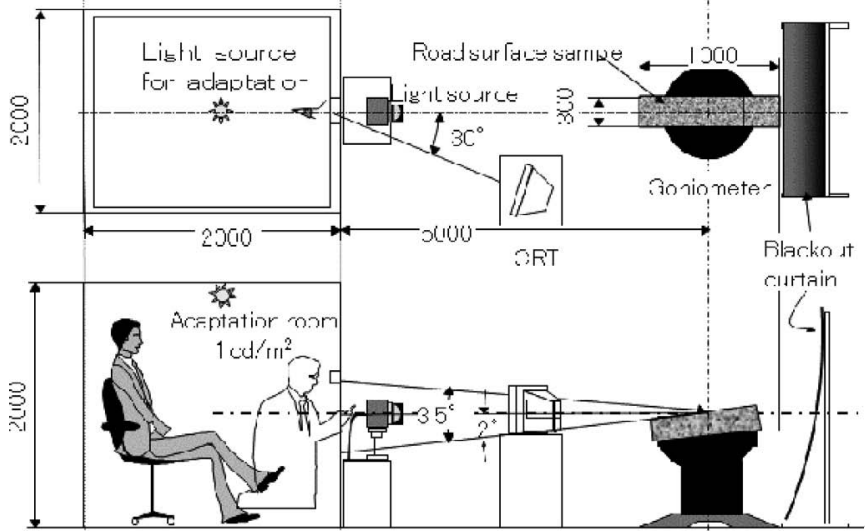

図 1 実験装置上配置

Fig.1 Experimental apparatus and arrangement.

(1) 路面サンプル

路面サンプルは屋外にて 7 年間経年使用したものを採用した．路 面サンプルのサイズは $300 \times 1000 \mathrm{~mm}$ で, 観測空正面に観測角 $3.5^{\circ}$ ， 光源加方の入射角 $2^{\circ}$ ，再帰反射角 $1.5^{\circ}$ となるように配置した (車 両前 $520 \mathrm{~m}$, 前照灯取り付计高さ $0.75 \mathrm{~m}$, 眼の高さ $1.2 \mathrm{~m}$ に相当) した. 路面サンプルの輝度は各光源で详成可能な $13 \mathrm{~cd} / \mathrm{m}^{2}$ に設定し た。観測者から見た路面业ンプルの視角サイズは 200' (水平方 向) $\times 40^{\prime}$ (鉛直厅向) と比較的小さな視対象であり，中心視による 明るさを評価することとなる。

(2) 観測室

観測室は観測空を設置し，観测密から被験者が路面サンプル上 CRTディスプレイを同時に見えるようにした，観測室の観測空付近 の内壁注，被験者の目を前照灯ロービーム環境の順応輝度に合わせ るようにするために，白色光で $\mathrm{lcd} / \mathrm{m}^{2}$ となるように照明した。

(3) CRTディスプレイ

LG 社製 14 インチ CRT Studio Works 575N を使用した。 CRT 画面 には路面サンプルを模擬したそれと浪ぼ同一視角サイズのマッチ ング刺激を呈示した。こ れを図 2 に示す。

視角サイズは $140^{\prime}$ (水 平方向) $\times 35^{\prime}$ (鉛直方向) である。マッチング刺激 の縡度は被験者がキーボ ーードを使って誦整できる ようにした。マッチング 刺激の周囲部は前照灯口 一ビーム順応輝度と同一 の $1 \mathrm{~cd} / \mathrm{m}^{2}$ に設定した.

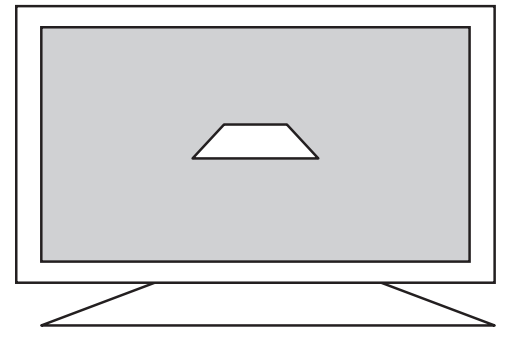

図2 CRT上のマッチング刺激

Fig.2 Reference visual target on the CRT for matching.
(4) 輝度 - 色度計測器

実験時における路面サンプル，光源，CRT の輝度と色度は，卜 プコン社製の分光放射計 SR-3A 在使用して測定した。

\section{2 光源と視対象の特性および被験者}

\section{(1) 光源の特性}

実験に使用した自動車前照灯の照明光源の特徴を表 1 に，そ水 らの分光分布を図 3 に示寸

表 1 照明光源の特徵

Table 1 Characteristics of the light sources.

\begin{tabular}{c|c}
\hline Type of light source & Type \\
\hline HID & D4S(水銀レス電球規格品) \\
\hline LED & Blue:InGaN+ Yellow phosphor \\
\hline Halogen & HB3(ハロゲン電球規格品) \\
\hline
\end{tabular}

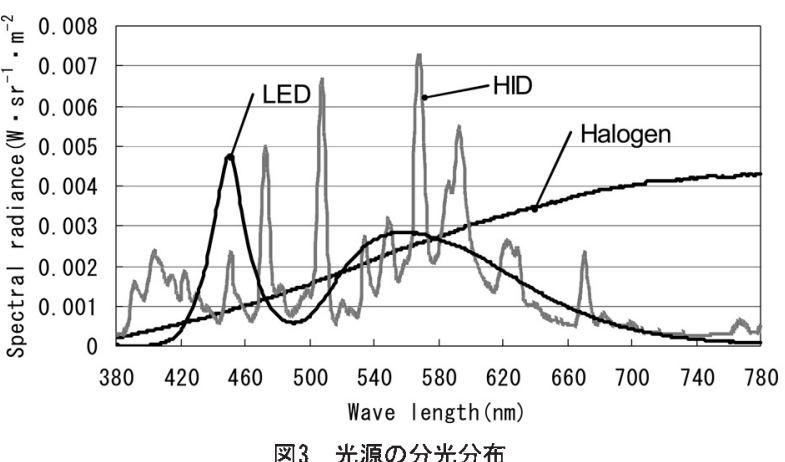

Fig.3 Spectral distributions of the light sources.

(2) 路面の特性

観測条件下における路面の分光反射率特性を図 4 に，3 種の照 明光源下に括ける路面色度を表 2 に示す。なお，この観測条件下 (観測角 $3.5^{\circ}$ ，人射角 $2.0^{\circ}$ ，再帰反射角 $1.5^{\circ}$ ) に求忛万路面の 反射率は2.5\%であった。

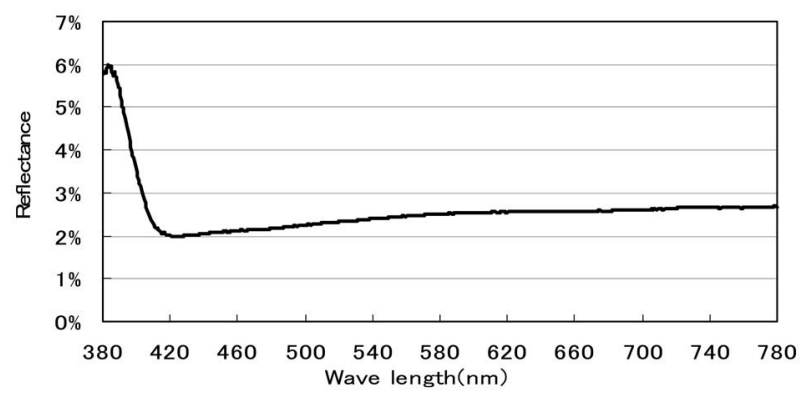

図4 路面サンプルの分光反射率分布

Fig.4 Spectral reflectance of the road surface sample.

表 23 種の照明光源下における路面サンプルの色度

Table 2 Road surface sample chromaticity

under the three types of illumination light sources.

\begin{tabular}{c|c}
\hline Type of light source & $x y$ chromaticity of the road surface \\
\hline HID & $x=0.3903, y=0.4067$ \\
\hline LED & $x=0.3530, y=0.3529$ \\
\hline Halogen & $x=0.4471, y=0.4129$ \\
\hline
\end{tabular}


(3) CRTディスプレイの特性

CRT ディスプレイは電源投入後, 1 時間放置して安定させた。安 定後の白色光 $(\mathrm{R}=\mathrm{G}=\mathrm{B})$ の)階調一輝度特性老図 5 に示す。

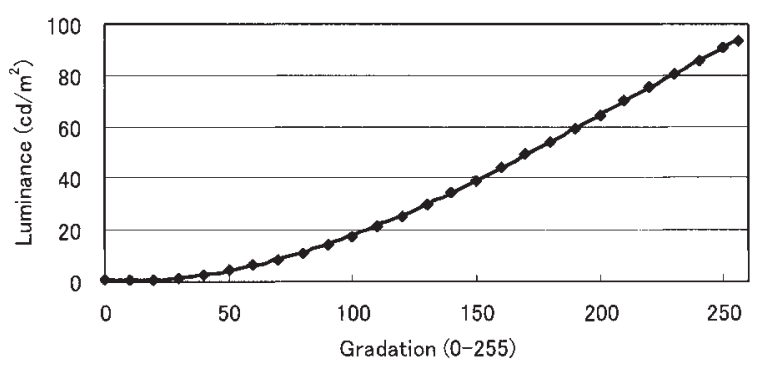

図5 CRTディスプレイの階調一輝度特性

Fig.5 CRT Gradation - luminance characteristics.

マッチング刺激の輝度を $13 \mathrm{~cd} / \mathrm{m}^{2}$ に，その周辺部の輝度を $1 \mathrm{~cd} /$ $\mathrm{m}^{2}$ に設定した時の $x y$ 色度を表 3 に示卞。

表 3 マッチング刺激の色度

Table 3 Characteristics of $x y$ Chromaticity of Matching Stimuli.

\begin{tabular}{c|c|c}
\hline Location & Disp. Luminance & $x y$ chromaticity \\
\hline Matching stimuli & $13 \mathrm{~cd} / \mathrm{m}^{2}$ & $x=0.283, y=0.286$ \\
\hline Surrounding area & $1 \mathrm{~cd} / \mathrm{m}^{2}$ & $x=0.264, y=0.254$ \\
\hline
\end{tabular}

（4）被験者

被験者江，年齢 25〜65才の男性 37 名，女性 3 名の計 40 名で, 平均年齢は 48 才，うち眼鏡着用者は 4 名である.

\section{3 実験方法}

光源間の明るさの評価測定は CRT ディスプレイ上にマッチング 刺激を呈示し，この刺激と所定の前照灯光源で照明さ扎た路面の明 るさが等価となる刺激煇度 (等価輝度； Leq) 計測することにより 行う，光源の相違が視対象の明るさに及ぼす影響恃，このマッチン グ刺激を基準として評価する。

(1) 実験準備

前照灯照明光源と CRT ディスプレイを 1 時間エイジングする.そ の後, 路面サンプルを輝度 $13 \mathrm{~cd} / \mathrm{m}^{2}$ に調整し, 更に 5 分程度安定さ せる。

被験者を暗室に入室させ 5 分間暗順応させる，その後，被験者を 観测室に入室させ， 5 分間観測密付近の内壁を観察させ前照灯口ビーム環境の順态輝度 $1 \mathrm{~cd} / \mathrm{m}^{2}$ に順応させる。

(2) 实験手順

実験開始前に, 被験者はCRT ディスプレイに表示したマッチング 刺激の最小輝度(階調 0 ) と最大輝度(階調 255) を確認する。

被験者は，路面年ンプルの明るさがマッチング刺激の明るさと同 一となるようマッチング刺激の階調を調整寸る. 実験者はその時の 階調值を記録する。記録された階調データは図 5 の階調一輝度特性 データを使用して輝度值に変換する。この輝度值を該当する路面步 ンプルの明るさに対寸る評佂值，即ち等価輝度 (Led) とする。

上記の手順にて前照灯 (光源) を交換し, Leqの測定を繰り返す. 3 種の光源の評価完了後, 被験者を交代させ実験を繰り返す, なお, 各光源に対する被験者の $L e q$ 測定回数は 1 回である.

\section{4 結果}

図 6 亿全被験者の等価輝度 (Led) の測定結果を示寸。

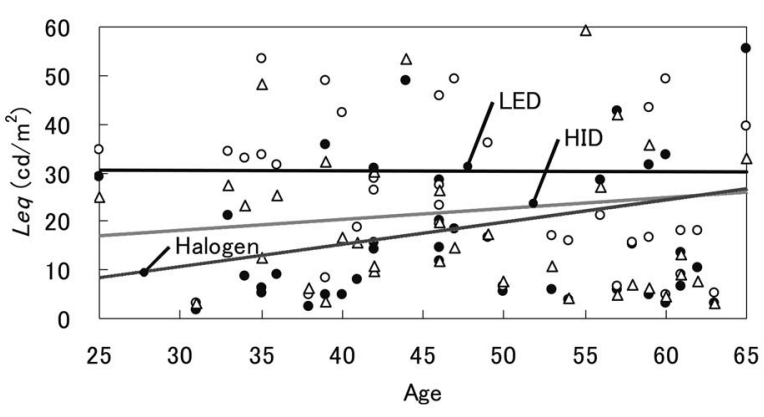

図6 各照明光源下における等価輝度Leqの測定結果

Fig.6 Measured equivalent luminance ( $L e q)$ under the different light sources.

図の横軸は被験者の年齢を，縦軸は等価輝度 $L e q$ を，図中の記

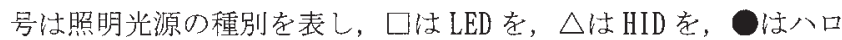
ゲンの結果を示している，各光源とも被験者によるバラッキが大 きい結果となっている。なお，図中の直線は，各光源に対して求 めた Leqの年龄に対する回帰直線である.

表 4 にLeqの全被験者に対寸る平均値, その標準偏差 $\sigma$, 比率, 回帰直楾の決定係数 $R^{2}$ とその傾きを示寸。なお，ここでRatio(比 率) とはHIDのLeq平均值を1として正規化した時の LED, 八ロダ ンのLeqの值である.

表 4 各照明光源下における等価輝度 $L e q$ 実験結果

Table 4 Experimental results of $L e q$

under the different light sources.

\begin{tabular}{c|c|c|c|c|c}
\hline $\begin{array}{c}\text { Light } \\
\text { source }\end{array}$ & $\begin{array}{c}\text { Leq } \\
\left(\mathrm{cd} / \mathrm{m}^{2}\right)\end{array}$ & $\sigma$ & Ratio & $R^{2}$ & Inclination \\
\hline \hline HID & 22.09 & 19.29 & 1.00 & 0.016 & 0.225 \\
\hline LED & 30.35 & 20.51 & 1.37 & 0.000 & -0.002 \\
\hline Halogen & 18.95 & 17.79 & 0.86 & 0.076 & 0.455 \\
\hline
\end{tabular}

※ $1 ;$ Rat $i o=$ (所定光源の平均 $L e q) /(\mathrm{HID}$ )平均 $L e q)$

上記の結果より,HID を 1 に正規化した時の LED の明るさはHID に対して 1.37 倍と高いが，八ロ夺ンは逆にHIDに対して 0.86 倍 と低い。これは照明光源の分光分布の相違の影響が考えられる。 また，八ロダンとHIDには加噛の影響が見受けられる．LED は八 ログンとHID と比較して被験者年齢層全般に渡って明るさが高い と評価している.

表 5 に，照明光源問の平均值の差の検定結果を示す. HID $\times$ LED の $p$ 值は 0.0671 で $5 \%$ に近いが, HIDXHalogenのp値は 0.4525 で有意差なし, LED $\times$ Halogen の p值は 0.0096 と $1 \%$ 有意であった。

表 5 各照明光源間の等価輝度 $L e q$ の平均値の差検定結果

Table 5 Verification results of the differences in Leq average value among the different light sources.

\begin{tabular}{c|c|c|c}
\hline & Dispersion & $p$-Value & Verification \\
\hline \hline HID vs. LED & 1366.80 & 0.0671 & $p>0.05$ \\
\hline HID vs. Halogen & 196.27 & 0.4525 & ----- \\
\hline LED vs. Halogen & 2598.97 & 0.0096 & $p<0.01$ \\
\hline
\end{tabular}


表 6 に各照明光源下における等洒輝度 Leqの平均值の結果, 三刺 激值 $(X, Y, Z$ そして色温度の測定結果をまとめた。

\section{表 6 各照明光源下における等価輝度 Leqの平均値,}

$$
\text { 三刺激値 }(X, Y, Z) \text { と色温度 }
$$

Table $6 L e q$, tri-stimulus values $X, Y, Z)$ and color temperature of each light sources.

\begin{tabular}{c|c|c|c|c|c}
\hline $\begin{array}{c}\text { Light } \\
\text { source }\end{array}$ & $\begin{array}{c}\text { Leq } \\
\left(\mathrm{cd} / \mathrm{m}^{2}\right)\end{array}$ & \multicolumn{3}{|c|}{ Tri-stimulus values } & \multirow{2}{*}{$\begin{array}{c}\text { Color } \\
\text { temp. }\end{array}$} \\
\hline \hline HID & 22.09 & 12.47 & 13.00 & 6.49 & 4242 \\
\hline LED & 30.35 & 13.01 & 13.00 & 10.83 & 5293 \\
\hline Halogen & 18.95 & 14.08 & 13.00 & 4.41 & 3092 \\
\hline
\end{tabular}

被験者全員の等佂輝度 $L e q$ の平均值之三刺激値 $(X, Y, Z$, 色温度 との関係教7 から図10 亿示寸.

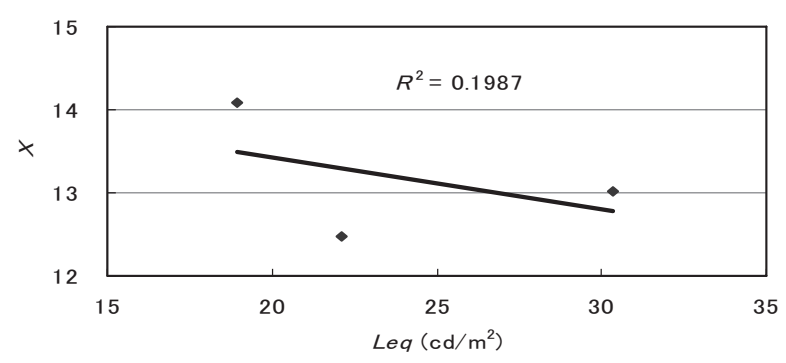

図 7 三刺激值 $X$ 亡等価輝度 $L e q$ の平均値との関係

Fig.7 Correlation between the mean Leq and the tri-stimulus value's $X$ of each light sources.

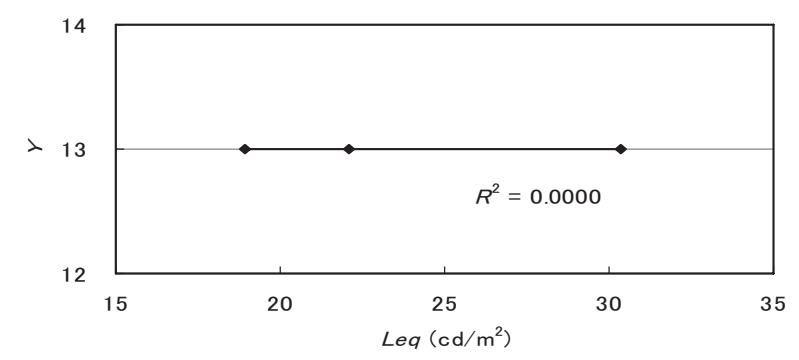

図 8 三刺激值 $Y$ と等価輝度 $L e a$ の平均值との関係

Fig.8 Correlation between the mean Leq and the tri-stimulus value's $Y$ of each light sources.

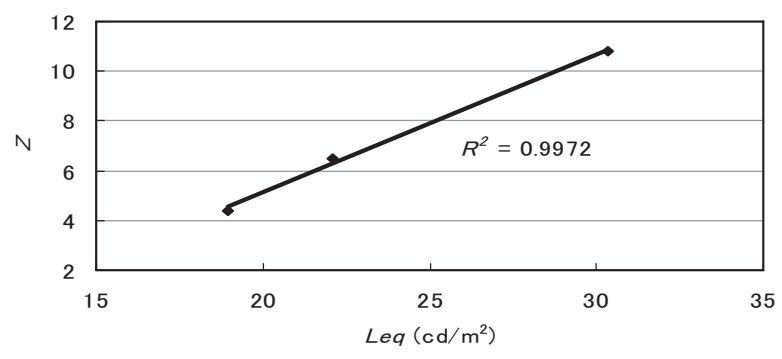

図 9 三刺激値 $乙 と$ 等価輝度 $L e q$ の平均值との関係

Fig.9 Correlation between the mean Leq and the tri-stimulus value's $Z$ of each light sources.

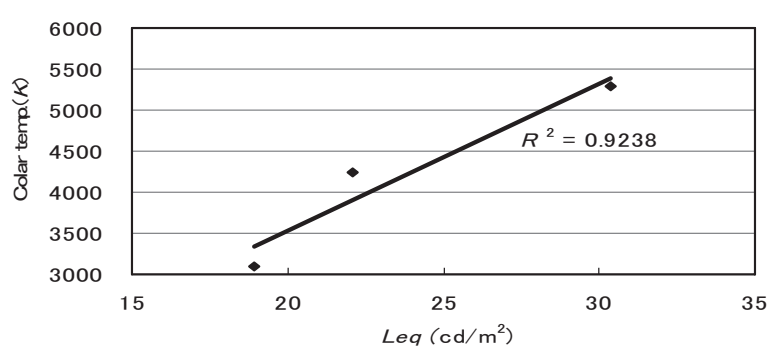

図 10 色温度と等価輝度 $L e q$ の平均值との関係

Fig.10 Correlation between the mean Leq and the color temperature $(K)$ of each light sources.

これらの結果より等価煇度 $L e q$ は三刺激值の Z 並びに色温度と の相関が強いと䎡える (図 9, 図 10 参照)。

$Z$ は 3 種ある眼の視細胞の中でも短波長に态答寸る $S$ 錐体の反 応である。亦色温度は短波長光成分の増加と共に上昇する。 こ 机らのことより今回の路面に対する明るさは光源の分光成分, 中 でも短波長光即ち青色光成分量の影響を受けることを示唆して いる.そこで加齢の影響並びに $S$ 錐体の反志を考慮した明るさに 関わる比視感度曲線の検討を実施した。

\section{5 解析}

(1) 加齢が明るさに与える影響の解析

加齢に伴う視覚特性の変化には, 眼球光学系と神経系の変化に よるものがある. 特に加齢に伴う眼球光学系の水晶体, 角膜の分 光吸収率の変化は広く研究されており, 日本人の年代別標準比視 感度は，日本工業規格 JIS S0031に揭載されている ${ }^{5}$

この年代別比視感度を図 11 に示す，横軸は波長 $(\mathrm{n} n$ ) ，縦軸は 刘数で表した視感効率である。なお，図中の太線は標準比視感度 曲線 $V(\lambda)$ を表す，加齢とともに $500 \mathrm{~nm}$ 以下の短波長光の視感効 率が低下するのが特徴的である。

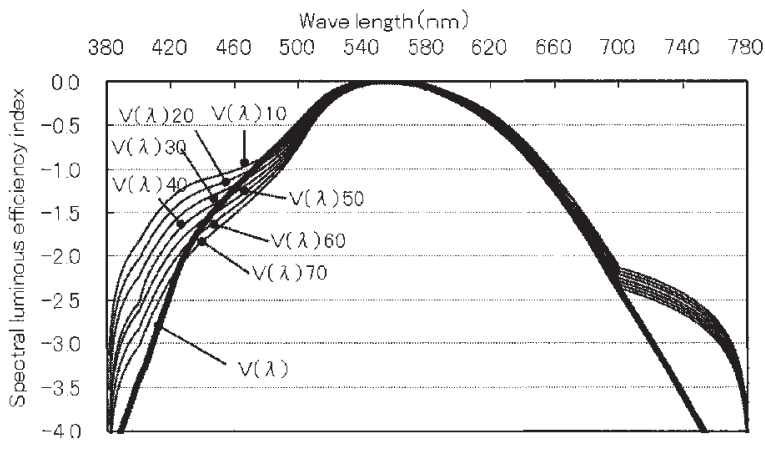

図11 日本人の年代別標準比視感度 ${ }^{5}$

Fig. 11 Standard spectral luminous efficiency of japanese people by age ${ }^{5}$.

そこで今回の実験に用いた路面サンプル亚びに各前照灯照明 光源の下で加齢の影響がざのように現れるかをこの年代別比視 感度を活用して検討することとした。

式 (1)は現在の CIE1931 表色系の測光量計算式である。この式 において $K m=683(\mathrm{~lm} / w) ， S(\lambda)$ に実験に用いた光源の分光放射工 ネルギ分布を， $\rho(\lambda)$ に路面サンプルの分光反啲率分布を， $V(\lambda)$ 
に年代別比視感度を代入し，LをLeq しして計算し，解析を䒠施し た.

$$
L=K m \int_{380}^{780} S(\lambda) \cdot \rho(\lambda) \cdot V(\lambda) \cdot d \lambda
$$

各光源に対可る年齢別 $L e q$ の計算結果を図 12 に，その結果を回 㷌直線に当てはめた時の傾き (Inclination) と決定係数 $R^{2}$ 表 7 に 示す。なお，表 7 は実験結果の傾きと決定係数も併せて示した。

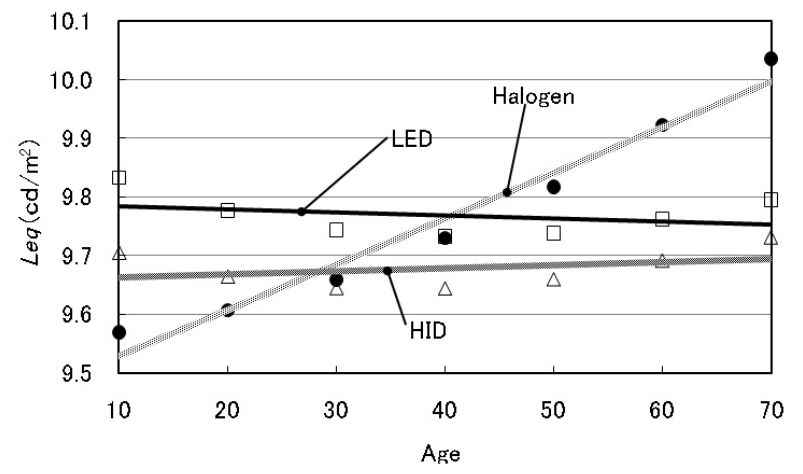

図12 各照明光源に対する年齢別Leq の变化 (計算結果)

Fig. 12 Changes in Leq with aging for each light sources

表7 実験結果と加㱓計算結果の回帰曲線係数の比較

Table 7 Comparison between the calculated results of aging and the experimental results.

\begin{tabular}{c|c|c|c|c}
\hline \multirow{2}{*}{$\begin{array}{c}\text { Light } \\
\text { source }\end{array}$} & \multicolumn{2}{|c|}{ Calculated results of aging } & \multicolumn{2}{c}{ Experimental results } \\
\cline { 2 - 5 } & Inclination & $\mathrm{R}^{2}$ & Inclination & $\mathrm{R}^{2}$ \\
\hline \hline HID & 0.001 & 0.122 & 0.225 & 0.016 \\
\hline LED & -0.001 & 0.104 & -0.002 & 0.000 \\
\hline Halogen & 0.008 & 0.969 & 0.455 & 0.076 \\
\hline
\end{tabular}

ハロゲンに関しては加齢変化の影響が著しいが，HID と LEDに関 して法とれほど顕著ではないといら結果が得られた。

加齢勃果 (傾き) の訃算結果と実験結果の企体的な傾向は一致し ている. 従って, 今回の結果に打ける年齢による違いは相対的に分 光視感度の加齢変化で定性的に説眀できると言える，しかし，高齢 者で八ロゲンが他の光源に比べて等価輝度 Leqが高い計算結果とな っており，实験值と買なる，そこで，光源間のLeqの差の原因を検 討するために， $S$ 錐体を考慮した比視感度曲線を立案し，各光源間 の明るさ(等仙輝度) の相違に関する原因解析を行なった。

（2） $S$ 錐体を考慮した明るさに関わる比視感度曲線の検討

現在の CIE1931 表色系の測光システムでは, 测光量計算式 (1) で 用いる標準比視感度, 寸なわちCIE $V(\lambda)$ は $S$ 錐体が輝度に害与し ないという前提で求められている ${ }^{6)}$.

しかし，実験から得られた結果は $S$ 錐体の感度領域である短波苌 成分が明るさに害与していることを示昗していることから，明るさ に対応する新をな分光視感度を $V_{R}(\lambda)$ と記すこととし， $V_{H}(\lambda)$ を式 (2)のように定義した。

$$
V_{h}(\lambda)=K \cdot G_{S}(\lambda)+V(\lambda)
$$

ここで $G_{S}(\lambda)$ は $S$ 錐体の分光感度，Kは山 $S$ 錐体の感度 $G_{S}(\lambda)$ が 寄与する割合走決定する係数である。なお， $S$ 錐体の分光感度 $G_{S}(\lambda)$ は Smith \& Pokorny")のデータを採用した。

今回の実験結果に最も適合する值を求めた結果， $K=1.49$ が得 られた。ここで， $G_{S}(\lambda) ， V(\lambda)$ ，及びKを1.49に設定した時の $V_{K}(\lambda)$ を図 13 に, 計算結果を表 8 に示寸, 標準比視感度曲線 $V(\lambda)$ に対して， $V_{R}(\lambda)$ は短波長側の感度を高めた形状となっている.

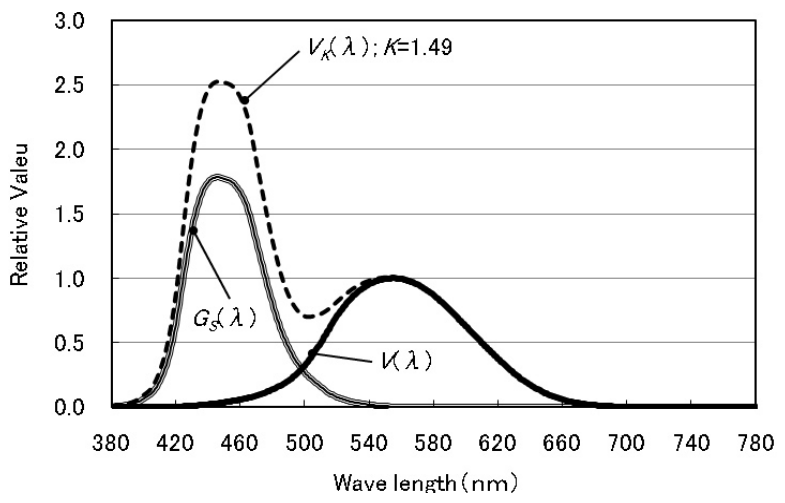

図 13 測光システムにおける分光視感度 $V k(\lambda)$ の提案 Fig.13 $V k(\lambda)$ for our proposed photometry system.

表 $8 L e q$ の実験値と $V_{K}(\lambda)$ による $L e q$ 計算値

Table 8 Leq experimental values and Leq values based on $V_{\kappa}(\lambda)$.

\begin{tabular}{c|c|c}
\hline $\begin{array}{c}\text { Type of light } \\
\text { source }\end{array}$ & $\begin{array}{c}\text { Leq } \\
\text { experimental value }\end{array}$ & $V_{K}(\lambda)$ \\
\cline { 2 - 3 } & 22.09 & $K=1.49$ \\
\hline HID & 30.35 & 22.67 \\
\hline LED & 18.95 & 29.15 \\
\hline Halogen & & 19.57 \\
\hline
\end{tabular}

前記の如く設定した $V_{K}(\lambda)$ に加齢効果を考虑できるようにす るために式(2) を更に改良した。これを式 (3)に示す。

$$
V_{\text {kage }}(\lambda)=K \cdot G_{S}(\lambda)+V_{a g e}(\lambda)
$$

ここで $V_{g g e}(\lambda)$ は前述の JIS S0031 の年代別比視感度における 年代別比視感度である. $V_{\text {Rage }}(\lambda)$ はその年代に対応した分光視感 度である。

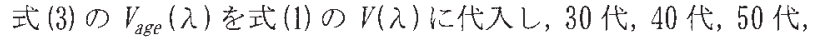
そして 60 代の各年齢別の Leq 各光源に対して求めた（Kは 1. 49). 結果を表 9 に示す. $L e q$ をLEDの計算結果で正規化したグ ラフを図14に示す.

表 9 実験結果の $\angle e q$ と $V_{K}(\lambda)$ による $L e q$ 計算値の比較 Table 9 Comparison between the calculated results of aging and the experimental results.

\begin{tabular}{c|c|c|c|c}
\hline \multirow{2}{*}{$\begin{array}{l}\text { Light } \\
\text { source }\end{array}$} & \multicolumn{2}{|c|}{ Calculated results of aging } & \multicolumn{2}{c}{ Experimental results } \\
\cline { 2 - 5 } & Inclination & $R^{2}$ & Inclination & $R^{2}$ \\
\hline \hline HID & -0.448 & 0.929 & 0.225 & 0.016 \\
\hline LED & -0.492 & 0.954 & -0.002 & 0.000 \\
\hline Halogen & -0.207 & 0.935 & 0.455 & 0.076 \\
\hline
\end{tabular}




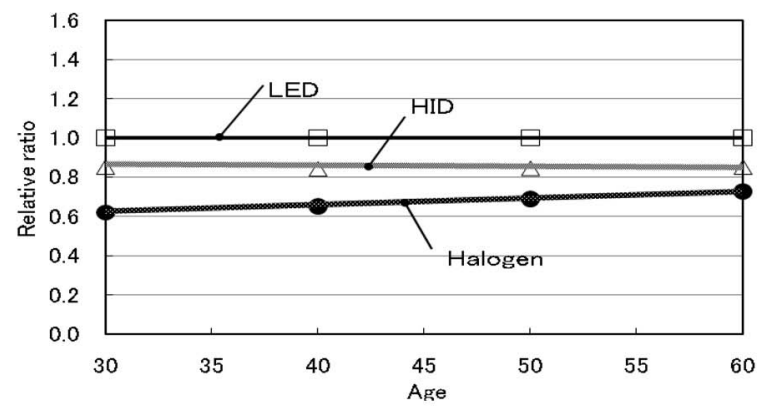

図 14 加㱓を考慮した $V_{k}(\lambda)$ によ Leq 正規化計算値 (LED=川)

Fig. 14 Changes in Leq with aging based on $V_{K}(\lambda)$.

図 14 の回帰直線群住図 6 のそれよよく似ている。また， $V_{K}(\lambda)$ によって加齢変化も精度よく説明できることから，今回提案した $V_{K}(\lambda)$ を用いた明るさ評洒法は妥当性が高いといえる。

\section{3．グレ一綿生地に対する実験 (実験 II)}

実験配置と実験方法は実験 I と同一で視対象のみグレー綿生地 に変更した。グレ一綿布地は路面サンプル上に敷いた，その呈示 輝度は実験 I と同じく各光源で達成可能な $9.6 \mathrm{~cd} / \mathrm{m}^{2}$ に設定した。 被験者は実験 Iの 40 名にて㤗施した。

\section{1 グレ一綿生地の反射特性}

観測条件下におけるグレ一綿生地の分光反射率老図 15 に, 各照 明光源下に㧍汀る色度を表 10 に示士。

路面サンプルは $400 \mathrm{~nm}$ 以下で反射率が增加する特性であったが (図 4 参照)，グレー綿生地は $680 \mathrm{~nm}$ 以上で反射率が增加する.

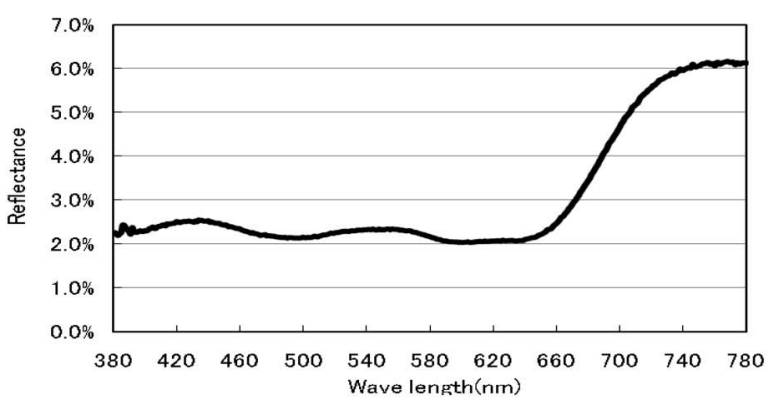

図 15 グレ一綿生地の分光反射率

Fig.15 Spectral reflectance of the grey cotton close.

表 10 各照明光源下におけるグレ一綿生地の色度

Table 10 Grey cotton close chromaticity under the three types of illumination light sources

\begin{tabular}{c|c}
\hline Type of light source & $x y$ chromaticity \\
\hline \hline HID & $x=0.3677, y=0.3924$ \\
\hline LED & $x=0.3265, y=0.3384$ \\
\hline Halogen & $x=0.4262, y=0.4055$ \\
\hline
\end{tabular}

\section{2 結果}

図 16 に全被験者の等価輝度 Leqの測定結果を，表 11 に Leqの 平均值, 標準偏差 $\sigma$, 比率, 回帰直線の決定係数 $R^{2}$ と傾きを示蓑. なお，図中の座標とシンボルは図 6 と同一である。

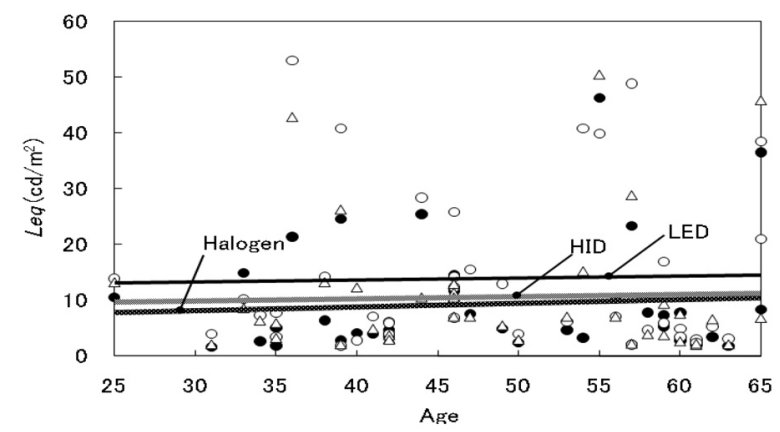

図 16 各照明光源下におけるグレ一綿生地の等価輝度 Leq の測定結果

Fig.16 Measured equivalent luminance $(\angle e q)$ of the grey cotton close under the different light sources.

\section{表 11 各照明光源下におけるグレ一綿生地 $L e q$ の実験結果}

Table 11 Experimental results of $L e q$

of the grey cotton close under the different light sources.

\begin{tabular}{c|c|c|c|c|c}
\hline $\begin{array}{c}\text { Light } \\
\text { source }\end{array}$ & $\begin{array}{c}\text { Leq } \\
\left(\mathrm{cd} / \mathrm{m}^{2}\right)\end{array}$ & $\sigma$ & Ratio & $R^{2}$ & Inclination \\
\hline \hline HID & 10.58 & 11.91 & 1 & 0.0069 & 0.0934 \\
\hline LED & 13.92 & 14.25 & 1.32 & 0.0017 & 0.0557 \\
\hline Halogen & 9.34 & 9.80 & 0.91 & 0.0387 & 0.1836 \\
\hline
\end{tabular}

3 種類の光源に対寸る $L e q$ の平均值の此率 (Ratio) 梳, 実験 $\mathrm{I}$ の路 面サンプルの実駼結果 1，1.37，0.86 に対して1，1３2，0.91 即ち LED $>H I D>$ Halogen で実験 I の結果と同傾向である. 次に, 実験 I で見られたハロゲン, HID 各光源の加齢効果は $1 / 2$ 程度に弱まって いる(表 4, 表 11 参照)．なお, Leqの標準偏差 $\sigma$ は実験 I の約 $1 / 2$ 程度に低下している。

表 12 に光源間の平均值の差の検定結果を示寸. 何れ光源閒の p>0.05で 5\%有意とはならなかったが, 平均値の差の傾向は実験 $\mathrm{I}$ と同じで，八ロゲンと LED 間の差が最も大きい結果となった。

表 12 各照明光源間の等価輝度 $L e q$ の平均値の差検定結果

Table 12 Verification results of the differences in Leq average value among the different light sources.

\begin{tabular}{c|c|c|c}
\hline & Dispersion & $p$-Value & Verification \\
\hline \hline HID vs. LED & 223.11 & 0.2587 & -- \\
\hline HID vs. Halogen & 30.60 & 0.6148 & -- \\
\hline LED vs. Halogen & 418.98 & 0.0991 & -- \\
\hline
\end{tabular}

表 13 に各照明光源下における三刺激値 $(X, Y, Z)$, 色温度と実験結 果の等価輝度 $L e q$ の全平均值を示寸.

\section{表 13 各照明光源下における等価輝度 Leqの全平均值、 三刺激値 $(X, Y, Z)$ と色温度}

Table $13 \mathrm{Leq}$, tri-stimulus values $(X, Y, Z)$ and color temperature of each light sources.

\begin{tabular}{c|c|c|c|c|c}
\hline \multirow{2}{*}{$\begin{array}{c}\text { Light } \\
\text { source }\end{array}$} & \multirow{2}{*}{$\begin{array}{c}\text { Leq } \\
\left(\mathrm{cd} / \mathrm{m}^{2}\right)\end{array}$} & \multicolumn{3}{|c|}{ Tri-stimulus values } & \multirow{2}{*}{$\begin{array}{c}\text { Color } \\
\text { temp. }\end{array}$} \\
\cline { 3 - 6 } & 10.58 & 9.00 & 9.60 & 5.87 & 4242 \\
\hline HID & 10.58 & 9.60 & 10.18 & 5293 \\
\hline LED & 13.92 & 9.64 & 9.60 & 3.98 & 3092 \\
\hline Halogen & 9.34 & 10.06 & & & \\
\hline
\end{tabular}


等価輝度 Leqの全平均值上三刺激值 $(X, Y, Z)$, 色温度上の関係を 図 17 から図 20 に示可. Leq は実験 $\mathbf{I}$ の路面サンプル実験と同じく 三刺激值の $Z$ との相関多強い, 一方, 色温度との相関は実験 $\mathrm{I}$ の結 果に比べやや弱まっている.

実験 I の解析と同様に $S$ 錐体の感度を考慮した式 (2)の分光視感 度 $V_{K}(\lambda)$ の係数 $K$ を求めた。結果を表 14 に示す。

グレ一綿生地の実験絬果に最も適合するK值は 0.627 であった。路 面サンプルの $K=1.49$ に比べ低い值となっている，路面サンプルは 短波長側で反射率が上昇しているが，グレ一綿生地は長波長側で上 昇している.この視対象の分光反射特性が係数 $K に$ 影響索与えたと 思われる.

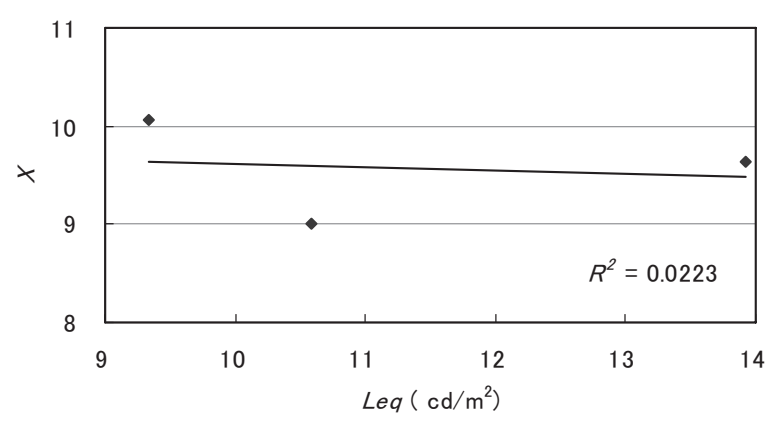

図 17 三刺激值 $X$ と等価輝度 $L e q$ の平均値との関係

Fig.17 Correlation between the mean Leq and the spectral tri-stimulus value's $X$ of each light sources.

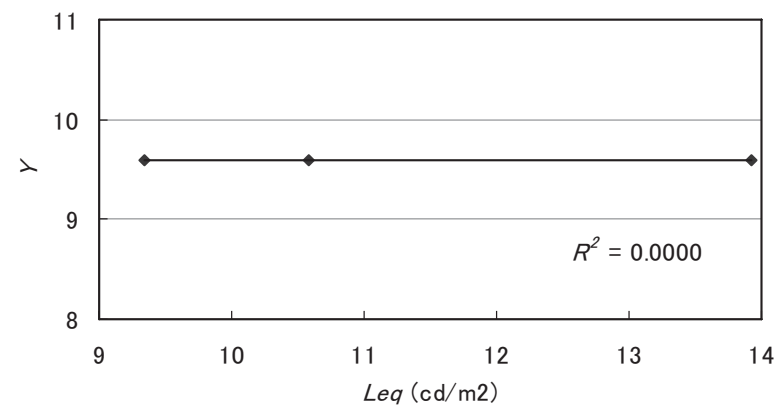

図 18 三刺激值 $\gamma$ と等価輝度 $L e q$ の平均值との関係

Fig. 18 Correlation between the mean $L e q$ and the spectral tri-stimulus value's $Y$ of each light sources.

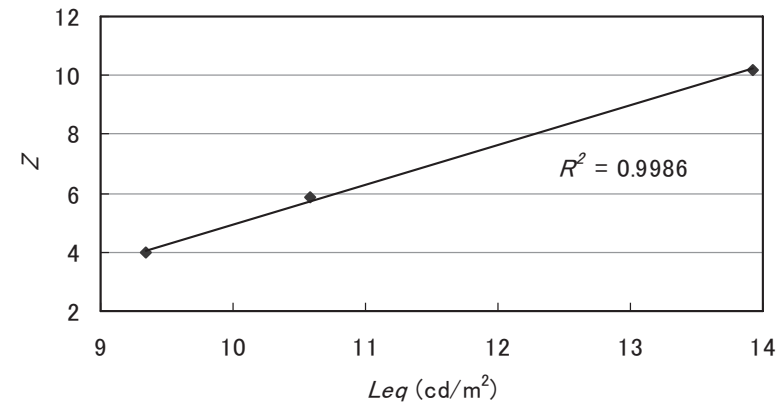

図 19 三刺激值 $Z$ と等価輝度 $L e q$ の平均值との関係

Fig.19 Correlation between the mean Leq and the spectral tri-stimulus value's $Z$ of each light sources.

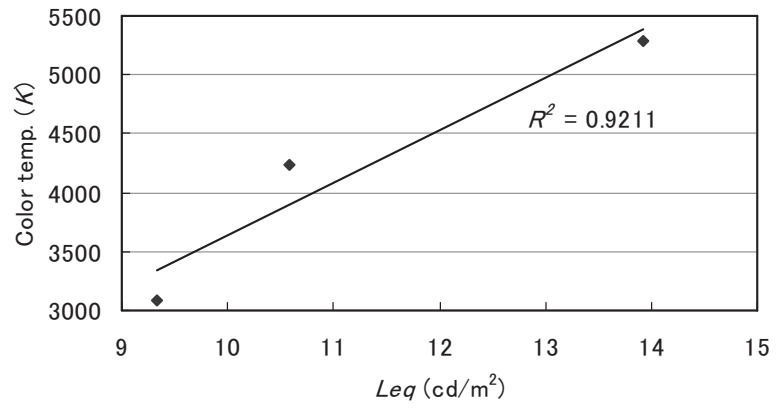

図 20 色温度と等佂輝度 $L e q$ の平均值との関係

Fig.20 Correlation between the mean $L e q$ and the color temperature $(K)$ of each light sources.

表 $14 L e q$ の実験値と $V_{k}(\lambda)$ による $L e q$ 計算値

Table $14 L e q$ experimental values and $L e q$ values based on $V_{K}(\lambda)$.

\begin{tabular}{c|c|c}
\hline $\begin{array}{c}\text { Type of } \\
\text { light source }\end{array}$ & $\begin{array}{c}\text { Leq } \\
\text { experimental value }\end{array}$ & $V_{K}(\lambda)$ \\
\hline \hline HID & 10.58 & $K=0.627$ \\
\hline LED & 13.92 & 9.86 \\
\hline Halogen & 9.34 & 12.04 \\
\hline
\end{tabular}

\section{4. まとめ}

本研究では前照灯の照明光源の分光分布が視対象の明るさに 及ぼす影響を調查した。照明光源はハロゲン，HID，LEDの白色系 光源 3 種類, 評価視対象は路面サンプル (実験 I) とグレ一綿生地 (実験 П) の無彩色系の 2 種類を選定した，視対象の視角サイズは $200^{\prime}$ (水平方向) $\times 40^{\prime}$ (鉛直方向) と比較的小さな視対象であ り，中心視の明るさ索評価した。

䒠験は視対象とマッチング刺激を渣接比較させ，明るさに関す る等洒煇度 (Le $d$ を測定することにより行い，視対象の明るさに 対する影響は $L e q$ の測定結果を測光システムの面から解析した。

(1) 明るさの実験結果

路面サンプル（実験 I ) に対する LED 光源の明るさは，HID の 1. 37 倍，八ロゲンの1.60倍であった。 LED と八ロゲン間に扝け る平均值の差は5\%有意であった.グレ一綿生地 (実験 П) に対する LED 光源の明るさはHIDの 1.32 倍, ハロゲンの 1.49 倍であった. LED 照明光源による視対象の明るさはグレ一蟐生地より路面サン プルにおいて明るさを向上させた。

消費電力の観点から見ると, LED 光源は HID の消費電力よりも 0.75 (= 1/1.35) 倍の電力で HID 相当の “明るさ”在得ることが 出来ることから, LED 光源は明るい光源であると共に, 省電力で 環境にもやさしい優れた光源であると言える。

(2) 照明光源による明るさ相違に関する解析結果

路面サンプル及びグレ一綿生地における光源間の明るさの相 違原因老等価輝度 $(L e q)$ と三刺激値 $(X, Y, Z)$ 並びに色温度の面か ら解析した。

その結果，明るさの指標である等価䪙度 Leq 路面サンプルで は三制激值 $X$ と色温度に対して相関が強い上いう結果となった。 一方，グレ一綿生地に対しては三刺激值 $X, Y$ との相関が高いと いら結果であった。 
(3) 測光システム面からの解析結果

Leqが三刺激值 $X$ との相関が高いという結果から，Leqに対応し た測光システムとして $S$ 錐体の分光感度も考慮した分光視感度 $V_{h}(\lambda)$ 学入した式 (2) を用いて実験絬果を解析した。

各実験結果を定量的に精度よく説明できる $K$ 值は, 路面サンプル で 1.49 ,グレ一綿生地では 0.627 であった。これは視対象の分光反 射特性により $K$ 值を修正する必要性を示唆している。

(4) 明るさの加齢効果について

路面の明るさ(実験 I )についてはハロゲンとHIDについては加齢 効果が見られた。これについては $V_{K}(\lambda)$ にJ S S0031 の年代別比視 感度における年齢の違いによる比を乗じて年齢別の等価渾度 Leqを 算出寸ることにより加齢変化を良く説明できることができること を示した。一方，グレ一綿生地 (実験 II) については八ロダン，HID の加齢効果法路面のそれに比べて $1 / 2$ 以下と弱くなった。これにつ いては視対象の分光反射率分布の影響が考えられる。

\section{5. 今後の課題}

明るさは中心視が最重要であるが，有效視野の明るさ，そして周 辺視も含めた存在空間の明るさについても今後研究を進める必要 がある。

また，実験に使用した路面サンプルとグレ一綿生地の何れの視対 象も表面色恃無彩色系である。交通案内標識の有彩色についても研 究在進める必要があるとともに視対象の分光反射率の影響につい ても莫に解析寸る必要がある。

照明光源の分光分布が視対象の明るさに与える影響については, 1960 年代に白色蛍光灯から.三波長型蛍光灯に進展寸る際に「同一煇 度でも明るさが異なる (B/L 効果)」ことが指摘され，1980 年代に CIE (国際照明委員会) はもとより国内でも数多くの研究成果の報告 がなされた ${ }^{81-11}$. 中でも照明学会の研究調查委員会では測光システ ムの面からの詳細な研究もなされた ${ }^{12)}$.そこでは 4 つの測光システ ムが提案され評伍されている ${ }^{13)-16)}$ ，今後の研究において，4 測光シ ステムの適用も検討したい.

今後とも自動車用照明機器の研究において視覚の科学面と人間 工学分野加らの実験と研究定進め, 交通安全・快適性向上に寄与し ていきたいと考えている.

\section{参考文献}

(1) Sivak, M., Schoett le, B., et al:LED Headlamps glare and color rendering, UMTRI-2003-39 (2003).

(2) Bullough, J. D., et al. :An investigation of headlamp glare, intensity, spectrum \& size, D0T HS 809672 (2003).

(3) 橋本 博, 野口 昌弘, 平尾保, 元木 正典: 高齢者に及ぼ す LED 前照灯の眩しさに関する検討, 平成 19 年 11 月, 自 動車技術会論文集, 38-6 (2007).

（4）塚田由紀，豊福芳典，森田和元，鈴木喜代司，井手勝幸: 白色 LED の色温度によるグレアの変化, H19 照学全大, p. 193 (2007JIS S0031).

（5）高齢者・障害者配慮設計指針一視覚表示物一年代別相対輝 度の求め方及び光の評洒方法 (2004).

(6) 色彩学会編・新編色彩科学ハンドブック【第 2 版】:pp. 397-400(1998)

(7) Smith, V. C. and Pokorny, J. : Spectral sensitjuity of the foveal cone photopigments between 400 and $500 \mathrm{~nm}$, Vision Research, 15, pp. 161-171 (1975).
(8) CIE TC1. 4: Light as a trueqisual quantity: Principles of measurement, CIE Pub. No. 41, CIE Central Bureau (1978).

(9) 廷々幸夫, 金谷末子, 猪原誠: 3 波長域発光形蛍光ランプの照 明特性, 照学誌, 63-5, pp. 260-271 (1979).

(10) 淵田隆義ほか: 3波長帯系蛍光ランプの照明効果，照学誌， 65-10, pp. 56-63 (1981).

(11) 納谷嘉信, 橋本健次郎: 高演色性蛍光ランプの照明下での明 るさ, 照学誌, 67-6, pp. 34-39 (1983).

(12) 照明学会・明るさ計量化研究調查委員会:明るさ測光システ 么の検討一明るさの計量化研究調查委員会報告書, JIER-018，平成2年8月，pp. 1-17 (1990)。

(13) Guth, S. L. and Lodge, H. R. : Heterochromatic additivity foveal spectral sensitivity, and new color mode l, J. 0pt. Am. 63 pp. 450-462 (1973).

(14) Yaguchi, H. and Ikeda, M: Subadditivity and super additivity in heterochromatic brightness matching, Vision Res. 23, pp. 1711-1718 (1983).

(15) Ware, C. and Cowan, W. : Spccification of heterochromatic brightness matches: A conversion factor for calculating luminances of stimuli that are equal in brightness; NRC Publication, No. 26055, National Research Council of Canada (1983).

(16) Nakano, Y. Ikeda, M. and Kaiser, P. K. : Contributions of the opponent mechanisms to brightness and nonlinear model, Vision Res. 28, pp. 799-810(1988).

（受付日2009年7月13日 / 採録日2010年3月8日)

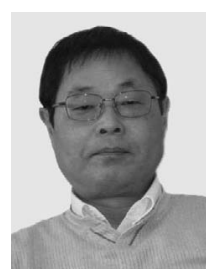

小林 正自（専阴会員）

柣小系製作所

广 424-8764 静岡県静岡市清水区北脇 500 1953 年生まれ。1975 年東海大学工学部光 学工学科卒業. 同年から同所に勤務。自動 車照明機器の基礎研究に従事. 自動車技術 会, 交通工学会等各会員.

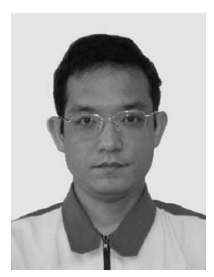

大川 正夫 (非会員)

䊉小系製作所

$\bar{T} 424-8764$ 静闹県静岡市清水区北脇 500 1966 年生まれ. 1984 年静阊県立島田工業 高等学校卒業. 同年, 検小系製作所に勤務. 自動車用前照灯，標識灯性能評価及び照明 機器技術開発に従事.

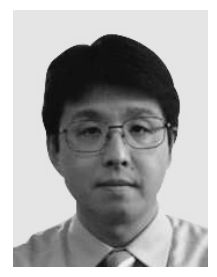

岡嶋 克典 (専門会員)

横浜国立大学大学院環境情報研究院

T240-8501 横浜市保土ヶ谷区常盤台 79-7 1990 年東京工業大学大学院総合理工学研 究科博士課程修了工学博士。同年加防衛 大学校に勤務. 2004 年加ら現所属。日本視 覚学会, 日本色彩学会, 日本光学会等各会 員. 